\title{
SPINAL INJURIES FROM SWIMMING AND DIVING TREATED IN THE SPINAL DEPARTMENT OF ROYAL PERTH REHABILITATION HOSPITAL: 1956-1978
}

\author{
By E. R. Griffiths, O.B.E., M.B., B.S.(Lond.), F.R.C.S.(Edin.), F.R.A.C.S. \\ Spinal Department, Royal Perth (Rehabilitation) Hospital, Shenton Park, \\ Western Australia
}

\begin{abstract}
Over the past 23 years, 67 patients have been admitted with spinal cord injuries resulting from swimming and diving. These numbers comprise 10.5 per cent of all traumatic spinal cord injuries received, and 20.6 per cent of all cervical spine injuries received. Ninety-five per cent of these patients were male, and more than three-quarters were young males under the age of 30 years. Two-thirds of these patients had permanent residual disability with an early mortality rate of 4.4 per cent.
\end{abstract}

Key words: Swimming and diving; fractured cervical spine; tetraplegia.

AUSTRALIA is a large country with a land area of approximately that of the United States of America, and is situated in the southern hemisphere in a tropical or sub-tropical zone. The major cities, where most of the population is centred, are situated on the coastline around Australia. The summers are long and hot for approximately six months of the year in the southern part of Australia, and all the year round in the rest of Australia. Swimming and diving are an everyday occurrence for most Australians. Australia is also a reasonably affluent society, and in my home city of Perth, there are many thousands of garden swimming-pools. During the hot summer months those situated inland without access to the coast, use farm dams and local rivers to cool off.

Beaches near the major cities are patrolled by the Surf Lifesaving Association which are entirely voluntary, and give very good service in rescuing and resuscitating those in difficulties on the beaches. Quite apart from spinal cord injuries, figures from the New South Wales Surf Lifesaving Association show that in a period of 3 years from 1974 there were 96 cases of immersion resulting in 29 deaths from drowning, with 67 survivors, the majority of the deaths being in the young Australian male.

Survival of the patient with a cervical spinal cord injury can be attributed to a great degree to the activities of voluntary organisations such as this, in carrying out immediate resuscitation and, of course, better methods of resuscitation at the emergency centres when the patient is accepted for treatment.

Of a total of 64I spinal cord injuries received at the Spinal Unit in Perth over the past 22 years, cervical injuries amounted to 336 (52.4 per cent) of all spinal injuries (Table I).

TABLE I

Royal Perth (Rehabilitation) Hospital Spinal Unit I956-I978

Total traumatic spinal cord injuries $=64 \mathrm{I}$

Total cervical injuries $\quad=336$

Proportion of cervical injuries $\quad=52.4 \%$ 
Taking cervical injuries alone, motor vehicle accidents accounted for I 85 $(55.4$ per cent), and aquatic sports (swimming and diving) accounted for $67(20.6$ per cent). Overall, swimming and diving alone accounted for 10.5 per cent of all spinal cord injuries received (Table II).

This is an injury of the male rather than of the female, and in the series presented there were 64 males ( 95.5 per cent), and only 3 female ( 4.5 per cent). This may mean that girls are less aggressive, or have more care for their well-being, or are more interested in displaying themselves in the latest bikini without actually entering the water (Table III).

The younger male is more frequently involved, and more than three-quarters were under the age of 30, and 9I per cent were under the age of 40.

The level of injury involved was predominantly that at $\mathrm{C}_{4-5}-6$ level with some multi-level injuries presenting, producing a total of 79 fractures or dislocations in 67 patients.

TABLE II

Royal Perth (Rehabilitation) Hospital Spinal Unit I956-I978

\begin{tabular}{|c|c|}
\hline Total cervical injuries & $=336$ \\
\hline Aetiology: & \\
\hline $\begin{array}{l}\text { MVA } \\
\text { Aquatic sport } \\
\text { (Swimming \& Diving) } \\
\text { (I0.5\% of } A L L \text { traumat }\end{array}$ & $\begin{array}{l}=\mathrm{I} 85=55.4 \% \\
=67 \quad=20.6 \% \\
\text { tic spinal cord injury) }\end{array}$ \\
\hline
\end{tabular}

TABLE III

Royal Perth (Rehabilitation) Hospital Spinal Unit I956-I978

\begin{tabular}{rlll}
\hline \multicolumn{2}{c}{67 Cervical injuries } & (aquatic sport) \\
\hline 64 & Male & $=$ & $95.5 \%$ \\
3 & Female & $=$ & $4.5 \%$ \\
\hline
\end{tabular}

TABLE IV

Age distribution

\begin{tabular}{lr}
\hline 13-19 & 23 \\
$20-29$ & 29 \\
$30-39$ & 9 \\
$40-49$ & $\mathrm{I}$ \\
$50-59$ & $\mathrm{I}$ \\
$60-69$ & $\mathrm{I}$ \\
$80-85$ & 2 \\
Not Known & $\mathrm{I}$ \\
Total & 67 \\
Under Age $30=52 / 67=77 \cdot 6 \%$ \\
Under Age $40=6 \mathrm{I} / 67=9 \mathrm{I} \%$ \\
\hline
\end{tabular}




\section{TABLE V}

Level of lesion

\begin{tabular}{rcc}
\hline Level & Fracture & Dislocation \\
\hline CI & I & I \\
2 & 3 & - \\
3 & 6 & - \\
4 & 8 & 6 \\
5 & I 8 & I \\
6 & I & 5 \\
7 & 4 & - \\
TI & - & - \\
2 & - & - \\
3 & - & 27
\end{tabular}

Total; 79 fractures or \# dislocations

Lesions at $\mathrm{C}_{4}-5-6=60=76 \%$

Some patients had fractures or fracture-dislocation at more than one level.

These figures are almost identical with those published by David Burke from Melbourne (1978). He quotes diving injuries as producing I I per cent of his total spinal injuries, 95 per cent of these being male, with a mean age of 27 years at presentation.

\section{Illustrative Case Histories}

Case No. I. F. G. (age I7): A surfing injury on the beach, 'dumped' by a large wave on to his head. Sustained compression fracture of the seventh cervical vertebra with transient paralysis of all four limbs with rapid recovery. C.A.T. scan measured $10 \mathrm{~mm}$ at the disc space between C6 and 7 and $10.5 \mathrm{~mm}$ behind the seventh cervical vertebral body. Just below minimal acceptable normal diameters. This boy proceeded to full recovery and persisted in surfing, and has been re-admitted on one occasion subsequently with acute hyperaesthesia of both upper limbs.

Case No. 2. D. S. (age I9): Diving into a shallow, rocky pool at a Jazz Concert where a considerable amount of alcohol was taken previously. Transient loss of all power in all four limbs, but when seen 2 hours later at the Emergency Centre, had resolved to a Brown-Sequard syndrome with motor loss in left upper and lower limbs. Proceeded to recovery but still has sensory disturbance and weakness in left upper limb as residual disability.

This is a hyperextension injury with contusion over the forehead on presentation, and fractures of the neural arches of the second and third cervical vertebrae. C.A.T. scan demonstrates a fracture of the neural arch and not spinous process fractures alone as suggested on the plain lateral $\mathrm{X}$-rays.

Case No. 3. P. R. (age 24): Also diving into the same rocky pool as Case 2 above. Both patients admitted within half-an-hour of each other, after consuming alcohol and, in addition, marihuana. A complete tetraplegia at C6 level on admission and has improved since to be $\mathrm{C}_{7}$ motor level with $\mathrm{T}_{\mathrm{I}}$ sensory level. Plain X-ray shows a mild compression fracture of the seventh cervical vertebra. However, tomographs show a severe fracture of the body of the sixth and seventh cervical vertebrae, and C.A.T. scan 
demonstrates the severe fracture of the vertebral bodies but with no gross narrowing of the neural canal in diameter.

Case No. 4. R. S. (Age 4I): Body surfing on a beach some 200 miles south of Perth and 'dumped' by a large wave. Had chest complications from inhalation of sea water

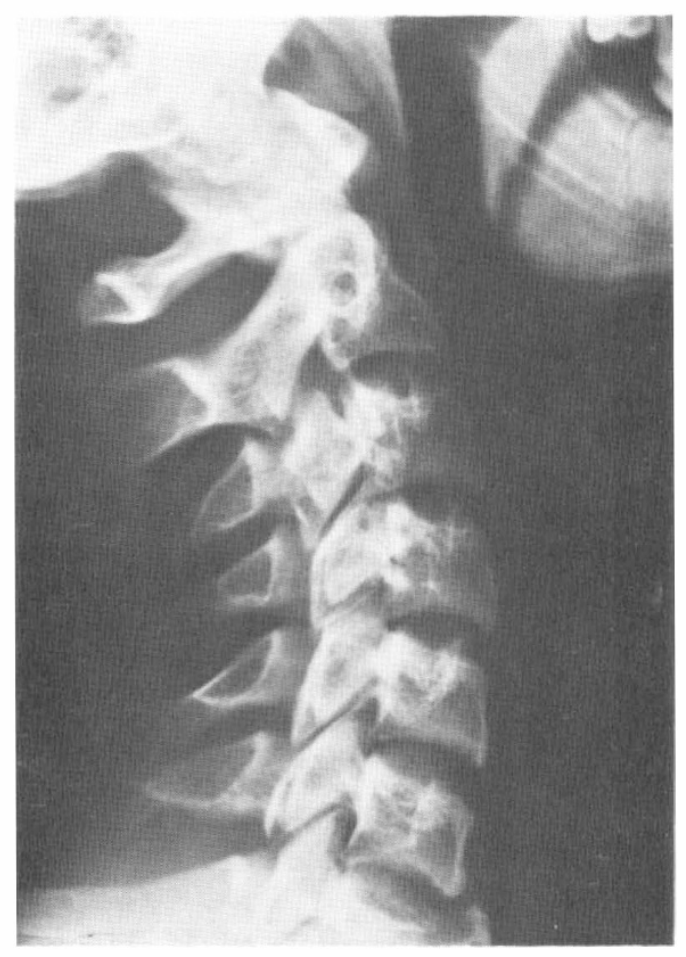

FIG. I

J. G. Case No. I. Compression fracture of seventh cervical vertebra.
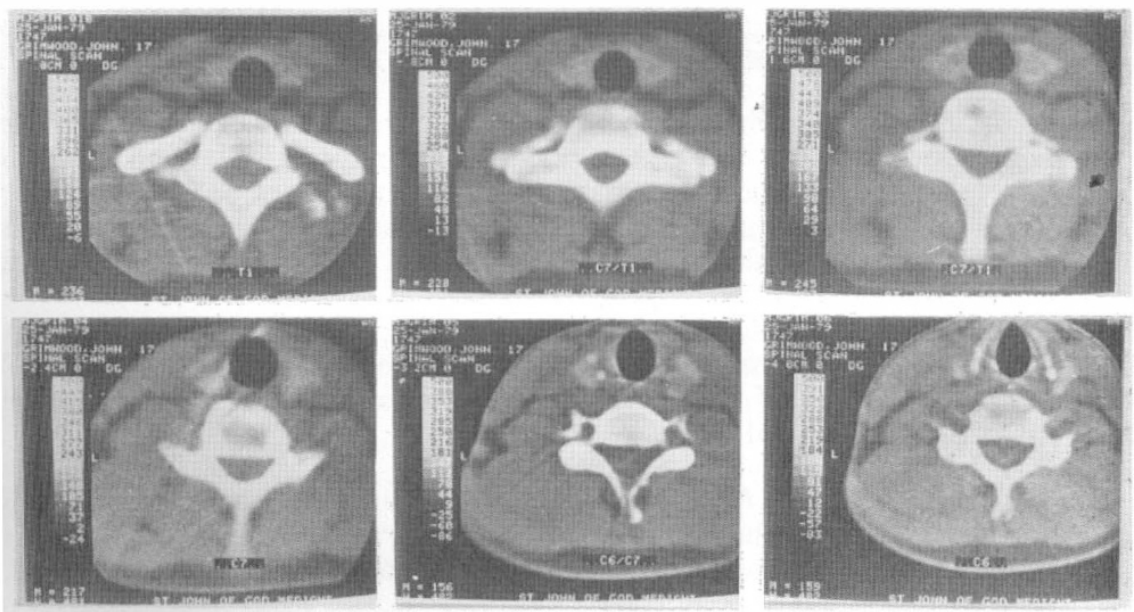

FIG. 2

J. G. Case No. I. C.A.T. scan from C6 through to TI demonstrating neural canal 


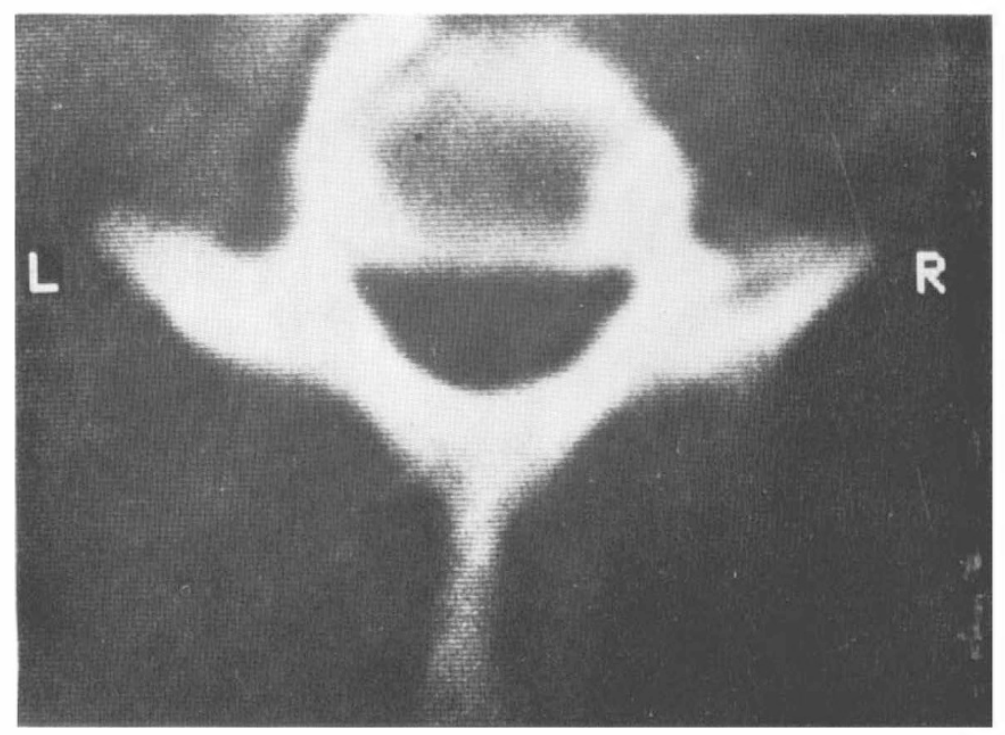

FIG. 3

J. G. Case No. I. C.A.T. scan showing deformation of vertebral body with narrowing of AP diameter of neural canal.
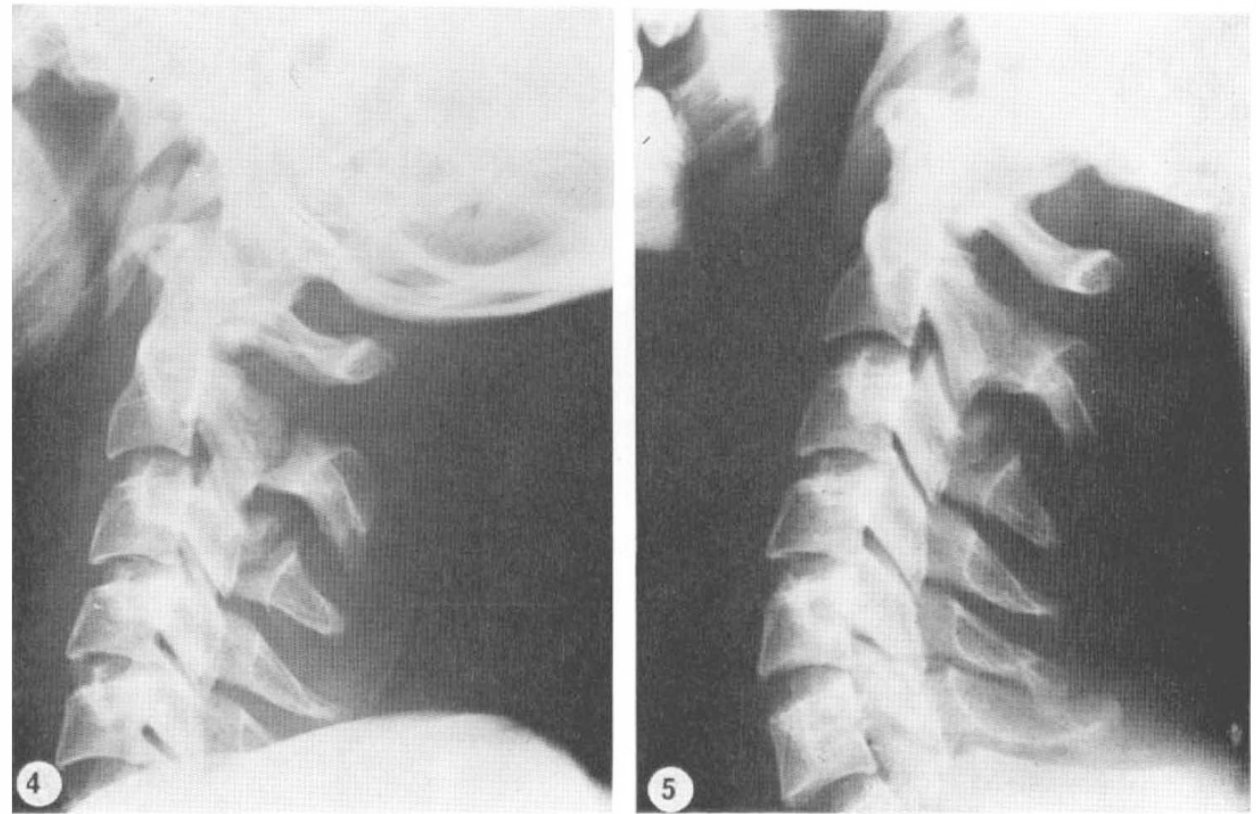

FIG. 4

D. S. Case No. 2. Hyperextension injury with fractures through neural arch of $\mathrm{C}_{2}$ and $\mathrm{C}_{3}$ vertebrae.

FIG. 5

D. S. Case No. 2. X-ray taken at II weeks post-injury showing union of neural arch of C2 vertebra. 

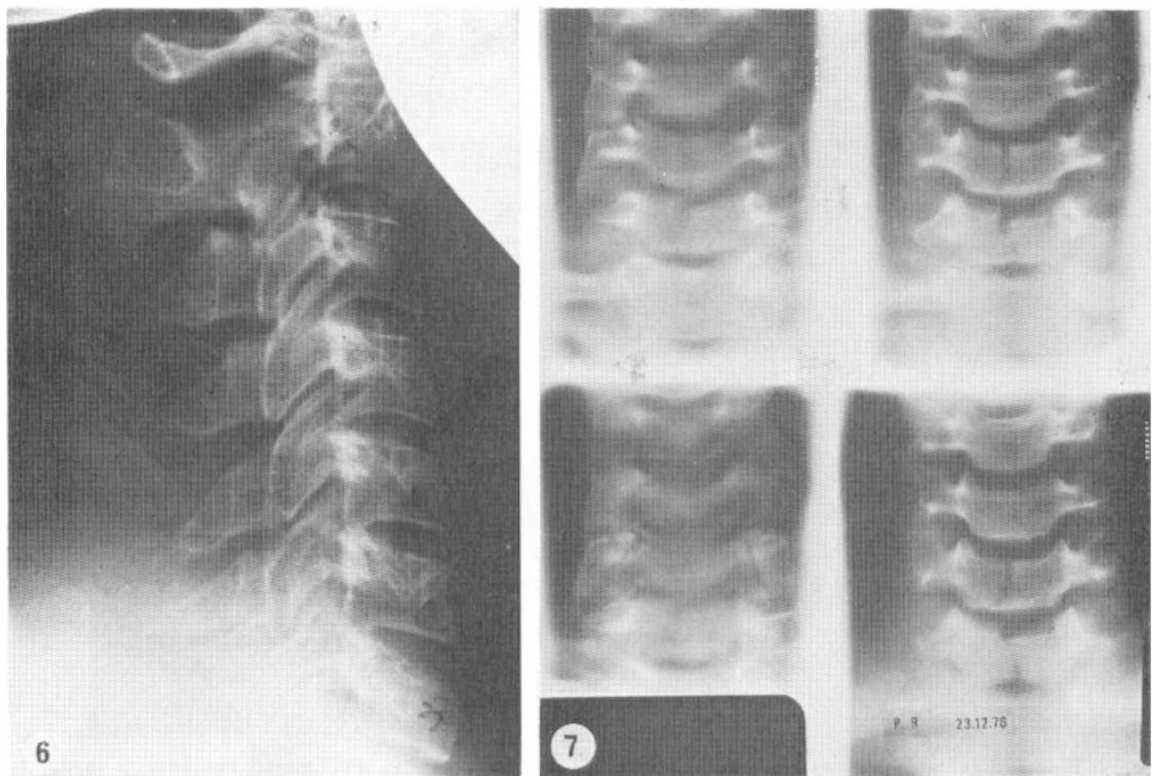

Fig. 6

P. R. Case No. 3. A plain lateral radiograph of cervical spine showing minimal compression fracture of seventh cervical vertebra.

FIG. 7

P. 'R. Case No. 3. AP tomographs of cervical spine showing vertebral body fractures of $\mathrm{C} 6$ and $\mathrm{C} 7$.
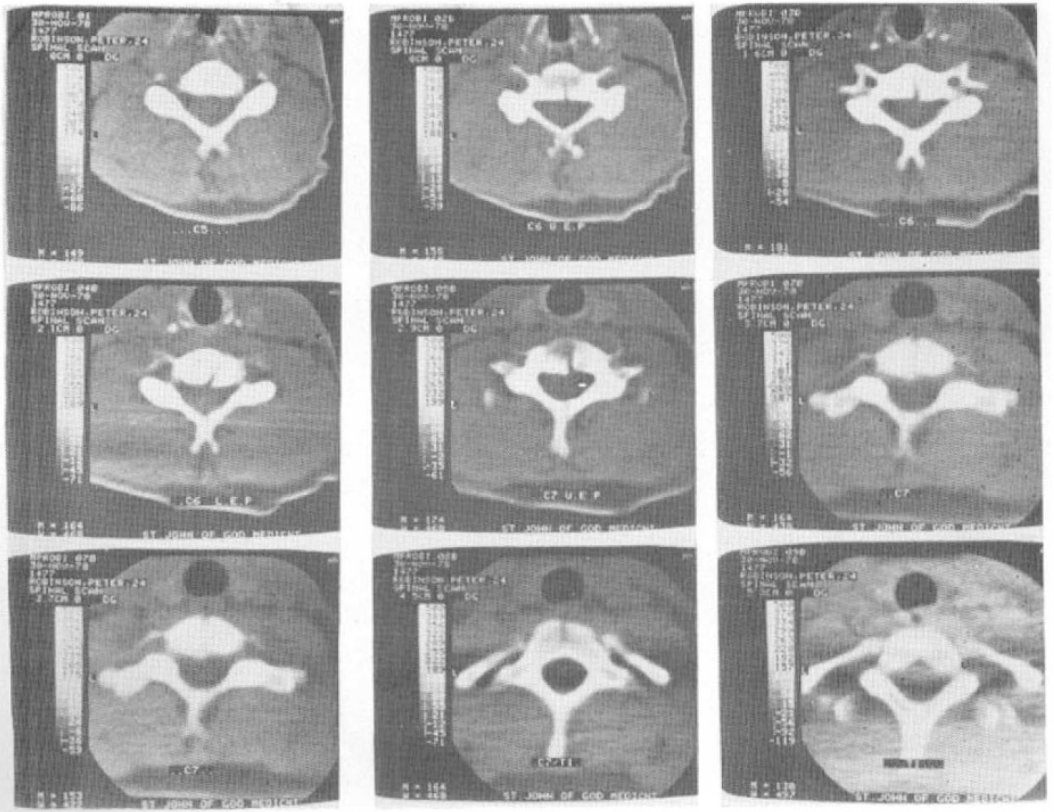

FIG. 8

P. R. Case No. 3. Serial C.A.T. scans of cervical spine from $\mathrm{C}_{5}$ through to TI demonstrating fractures and deformation of vertebral bodies of $\mathrm{C} 6$ and $\mathrm{C}_{7}$ vertebrae. 

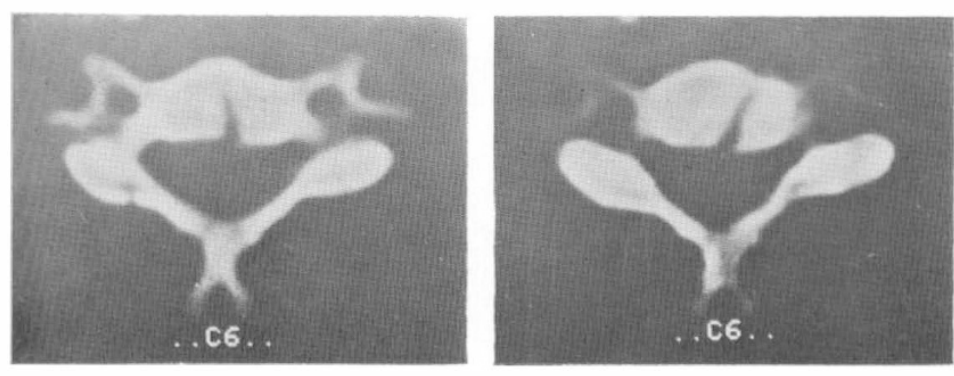

FIG. 9

P.R. Case No. 3. Enlarged C.A. T. scan demonstrating fractures of vertebral bodies and neuralarch of C6 and $\mathrm{C}_{7}$.
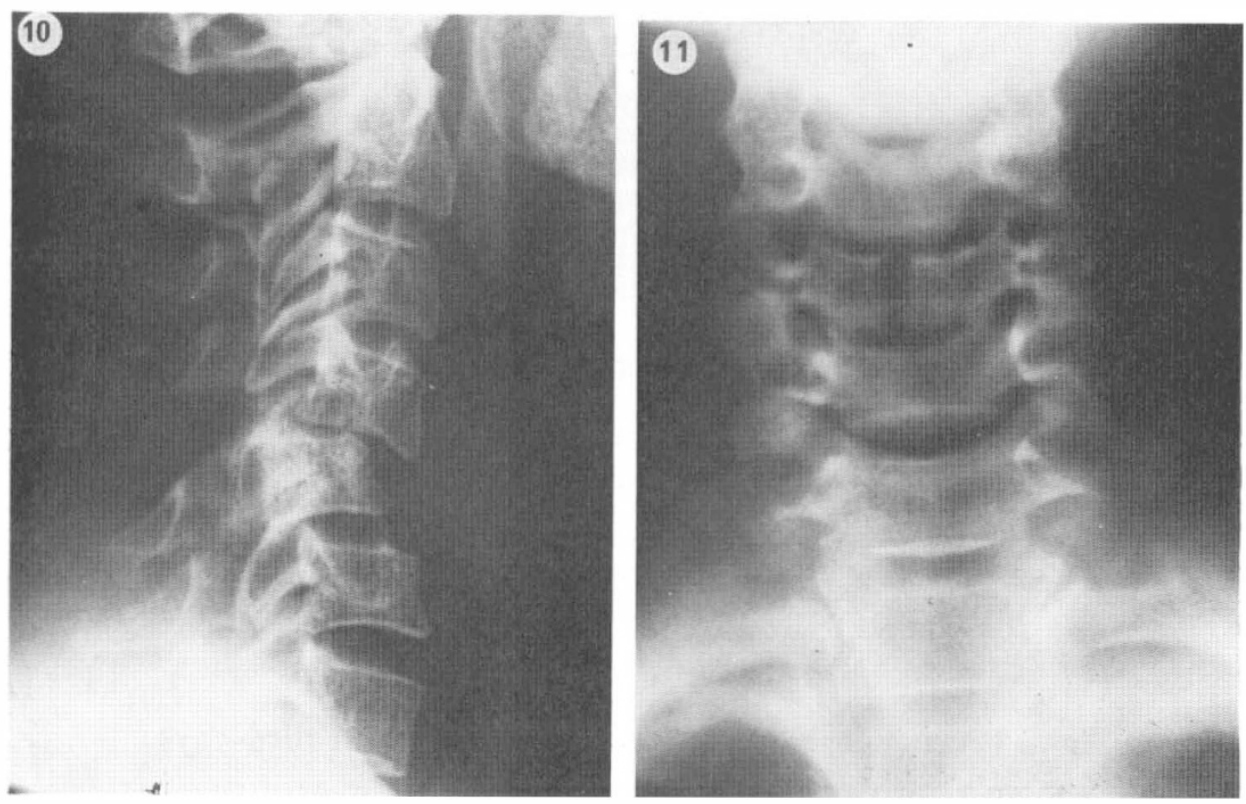

FIG. IO

R. S. Case No. 4. A lateral radiograph of cervical spine demonstrating retropulsion of the vertebral body of $\mathrm{C} 5$.

FIG. II

R. S. Case No. 4. AP tomograph showing fracture of vertebral body of $\mathrm{C}_{5}$ with a wide separation. 

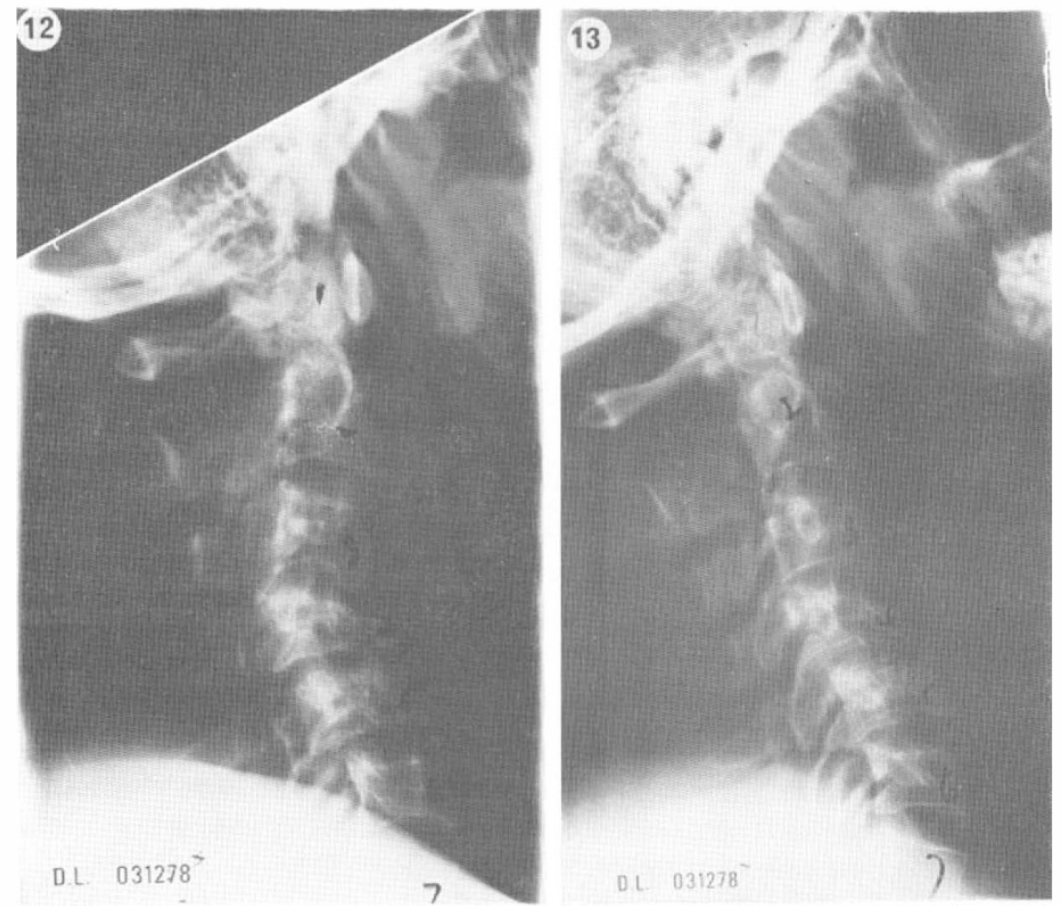

FIG. I2

D. L. Case No. 5. Lateral radiograph of cervical spine showing severe compression fractures of $\mathrm{C}_{4}$ and $\mathrm{C}_{5}$ vertebral bodies with severe posterior displacement.

FIG. I3

D. L. Case No. 5. Lateral radiograph of cervical spine following application of cervical traction.

and required tracheostomy. At first was tetraplegic at $\mathrm{C}_{4}$ level and has now resolved and stabilised at a permanent level of $\mathrm{C}_{5}$ tetraplegia. X-rays demonstrate a severe retropulsion of the body of the fifth cervical vertebra with forward dislocation of $\mathrm{C}_{4}$ upon $\mathrm{C}_{5}$.

Case No. 5. D. L. (Age 27): A young man who was fishing on board a boat on the Swan River and consuming Ouzo at the rate of half a tumbler every ro minutes. The boat grounded on a sandbar and in his confused state he did not appreciate that this implied

\section{TABLE VI}

Royal Perth (Rehabilitation) Hospital Spinal Unit 1956-1978

67 Cervical Lesions

\section{Neurological lesion}

Complete tetraplegia

Incomplete tetraplegia

$$
\left.\begin{array}{l}
=33(50 \%) \\
=\mathrm{II}
\end{array}\right\} 66 \%
$$

Recovery to minimal residual lesion or normality $=23$ 


\section{TABLE VII}

\section{Royal Perth (Rehabilitation) Hospital Spinal Unit I956-I978}

$\left.\begin{array}{cc}\text { Mortality } & \\ \text { Early deaths (first I2 months) } & =3(4.4 \%) \\ \text { Late deaths (2-I0 years) } & =4 \\ \text { Total } & =7(10.5 \%) \\ \text { Causes of mortality } & \\ \text { Respiratory }=4 \\ \text { Suicide }=1 \\ \text { Cardiac Failure }=2\end{array}\right\}$ (at Io years)

shallow water, and dived in to push his boat off. He had severe fractures of the fourth and fifth cervical vertebrae with retropulsion of the bodies of $\mathrm{C}_{4}$ upon $\mathrm{C}_{5}$ and $\mathrm{C}_{5}$ upon C6. He was tetraplegic initially at $\mathrm{C}_{4}$, requiring tracheostomy and assisted respiration and has remained static at the fourth cervical level, both sensory and motor.

Of the 67 cervical injuries, 50 per cent had complete tetraplegia, and a further II had incomplete tetraplegia, giving a total of 66 per cent with a major disability.

The mortality rate was 4.4 per cent in the first 12 months, mainly with respiratory problems in the few elderly people in this series. A further 4 cases succumbed, giving an overall mortality rate over 22 years of 10.5 per cent.

\section{SUMMARY}

Fracture of the cervical spine from swimming or diving is primarily an injury of the young, active male, two-thirds of whom remain with a major disability. Life expectancy of the majority of this group is in excess of 30 years with present management in developed countries. This implies a high cost to the state in terms of supportive finance and manpower. In Australia, swimming and diving injuries account for 10.5 per cent of all cord injuries received.

\section{RÉSUMÉ}

La fracture cervicale de l'épine dorsale provenant de la nage ou du plongeon est principalement attribuée aux jeunes hommes actifs dont les deux tiers restent avec une grave infirmité. La dureé de l'existence dans la majorité de ce groupe est au dessus de trente ans grâce aux soins reçus dans les pays dévelopès. Cela implique a l'état de la main d'oeuvre et des finances importantes. Les accidents dus à la nage et au plongeon en Australie comptent pour $10.5 \%$ de tous les accidents à l'épine dorsale.

\section{ZUSAMMENFASSUNG}

Von Frakturen der Halswirbelsäule durch Schwimmen-oder Tauchunfälle in jungen, aktiven Mannern, zwei-drittel verbleiben mit dauernden, beträchtlichen Beschädigungen. Die Lebenserwartung der Mehrzahl dieser Gruppe Ist länger als 30 Jahre mit dem augenblicklichen Behandlungsstandart der entwickelten Länder. Dies führt zu hohen Kosten für die Staaten insofern als Unterhaltskosten und Beihilfen. In Australien, Schwimm-und Tauch-unfälle kommen zu I0.5\% aller Rückenmarks Verletzungen.

\section{REFERENCES}

Hall, John C. \& BuRKe, David C. (1978). Diving injury resulting in tetraplegia. Med. $\mathcal{F}$. Aust. I, I7I. 